\title{
The Association between Ethical Decision-Making, Job Satisfaction, Organisational Commitment and Selected Demographic Variables
}

\author{
KAMARUL ZAMAN AHMAD \\ Faculty of Business and Accountancy \\ Universiti Malaya \\ SHARIFAH HASLINDA SYED ALWEE \\ ZETTY ZAHUREEN MOHD. YUSOFF \\ SUZANA IDAYU WATI OSMAN \\ SITI NORMAH AWANG TUAH \\ Graduate School of Management \\ Universiti Putra Malaysia
}

\begin{abstract}
Job satisfaction and organisational commitment are variables that have been frequently studied. However, the relationship between ethical decision-making and these two variables are seldom explored. This study conducted on 200 employees from public and private companies in various parts of Kuala Lumpur, aims to investigate the relationship between these three variables. Instruments were used from Paolillo \& Vitell (2002), Hunt, Wood \& Chonko (1989) and Dubinsky \& Hartley (1986) to measure ethics, organisational commitment and job satisfaction respectively. Results show that there is a positive correlation between ethics and organisational commitment and between job satisfaction and organisational commitment. However, contrary to expectations, there is no significant correlation between ethics and job satisfaction. The negative correlation between organisational commitment and position ( $r=-0.288, p<0.1)$ suggests that people higher up in the hierarchy are less committed towards the organisation. The absence of any significant correlation between ethics and age, experience, and position is also contrary to previous studies conducted in the West. This suggests that, unlike the West, ethics does not increase or decrease with age, experience, and position.
\end{abstract}

\begin{abstract}
ABSTRAK
Kepuasan kerja dan komitmen organisasi adalah pembolehubah-pembolehubah yang kerap dikaji. Walau bagaimanapun, hubungan antara pembuat keputusan beretika dan kedua-dua pembolehubah jarang dikaji. Kajian ini dibuat ke atas 200 orang pekerja yang terdiri daripada syarikat am dan prebet di Kuala Lumpur. Ia bertujuan untuk mengkaji perhubungan di antara tiga pembolehubah-pembolehubah tersebut. Borang soal-selidik daripada Paolillo \& Vitell (2002), Hunt, Wood \& Chonko (1989) dan Dubinsky \& Hartley (1986) digunakan untuk mengukur etika, komitmen organisasi dan kepuasan kerja. Hasil kajian menunjukkan terdapat korelasi positif di antara etika dan komitmen organisasi dan di antara kepuasan pekerjaan dan komitmen organisasi. Walau bagaimanapun, tidak seperti yang dijangka, tiada korelasi yang signifikan di dapati di antara etika dan kepuasan kerja. Korelasi negatif di antara komitmen organisasi dan kedudukan ( $r=-.288, p<0.1)$ menunjukkan bahawa pekerja yang berpangkat tinggi kurang komitmen terhadap organisasi. Ketiadaan korelasi yang signifikan di antara etika dan
\end{abstract}


umur, pengalaman dan kedudukan adalah bertentangan dengan kajian yang dibuat di barat. Ini menunjukkan bahawa, tidak seperti di barat, etika tidak bertambah atau berkurangan dengan umur, pengalaman dan kedudukan.

\section{INTRODUCTION}

The area of business ethics has received considerable attention from the corporate, academic and public sectors over the past decades. As awareness of ethical business behaviour is increasing worldwide, it is therefore important for business executives to develop an understanding of the ethical decision-making process, or more precisely, the correlates of ethics. Business ethics can be regarded as the application of general ethical ideas to business behaviour. In today's competitive business environment, many companies try to get by with unethical business practices in order to be sustainable. With the increased number of cases of reported fraud and mismanagement of large and small firms, greater focus has now been given to ethics in business. Besides, more and more businesses are now realising that unethical behaviour is costly to the firms, their employees, their investors and society.

Consequently, analysis have given much consideration in identifying the correlates of ethics, which can be job satisfaction and organisational commitment. In the light of these considerations, it is the primary aim of this research to investigate the correlation between ethical decision-making, job satisfaction, and organisational commitment. The correlation of these three variables with the demographic variables such as age, experience, qualifications and position are also examined as a secondary aim of this research.

\section{LITERATURE REVIEW}

\section{Ethics}

Business ethics comprise moral principles and standards that guide behaviour in the world of business (Ferrell \& Gresham, 1985). Ethics can be regarded as the study of standards of conduct and moral judgement, or the concept of right and wrong behaviour. Ethics can determine if our actions are moral or immoral. It deals with the fundamental human relationships - how we think and behave towards others and how we want them to think and act towards us.

Perceived unethical practices can be defined as the degree to which a respondent agrees that a situation has a problematic ethical context (Hunt \& Vitell, 1986). An individual should be able to perceive that an ethical dilemma exists before he or she will engage in the process of ethical decision-making. According to Hunt \& Vitell (1986), perception of an ethical problem triggers the ethical decision-making process. A number of studies also examined socio-demographical influences on ethical decision-making. Age was found to be among the factors that significantly influence an individual's ethical values. Also, gender was found to be a significant variable influencing ethical or unethical behaviour (Glover, Bumpus, Sharp \& Munchus, 2002). Mehta \& Keng (1984) found that job position, age and income were significantly correlated to perceptions of unethical situations in that the higher the position, age or income of the executives, the more unethical the situations were perceived.

\section{Job Satisfaction}

Job satisfaction has been defined as a constellation of a person's attitudes toward or about a job as a whole. There are many theories of job satisfaction, some of which are now of historical interest (e.g. Herzberg, Mausner, \& Snyderman's 1959) Two-Factor theory. Some have not been well supported by empirical research (e.g. need comparison theories) and a few show promise of becoming major theories (e.g. high performance cycle and value theory), but relatively little work has been done to develop comprehensive theories of job satisfaction (Dipboye, Smith \& Howell, 1994). In conclusion, it can be said that there are 
considerable differences between the theories of job satisfaction. Consequently, the current research treats job satisfaction as a constellation of a person's attitudes towards or about a job as a whole, rather than examining its separate facets.

Data suggest that global job satisfaction does tend to increase with age for all demographic groups, including women and minorities (Bourne, 1982 \& Rhodes, 1983). However, the only facet satisfaction measure that has consistently increased with age across studies is work facet satisfaction (Hunt \& Saul, 1975; Rhodes, 1983; Bourne, 1982). One explanation can be provided by the gravitational hypothesis (Wilk, Desmarais \& Sackett, 1995), which state that people tend to move towards and actually end up in jobs for which they are most suited. Another possible explanation is that people often perceive that, as they get older, they will have fewer job opportunities (Pond \& Geyer, 1987) and as a consequence, become more appreciative of, and less irritable about their job situations. Apart from age, tenure was found to moderate the relationship between the person and the environment, in that teachers with longer tenure generally fit the school better than their colleagues with shorter tenure (Ostroff \& Rothausen, 1997).

The argument whether men, by virtue of their sex alone, tend to be more satisfied in their jobs than women (or vice versa) was aptly summarised by Hulin \& Smith (1964). They maintained that no sex differences in job satisfaction exist and that any sex differences are really surrogates for differences in pay, education, tenure, and job level. Subsequent research seems to corroborate their view. For instance, Brush, Moch, \& Pooyan (1987), and Smith, Olsen, \& Falgout (1991) reported no difference between the global job satisfaction of men and women. Apart from global job satisfaction, there are also, no consistent differences in facet satisfaction between the sexes. Both men and women have reported satisfaction with intrinsic (e.g. job autonomy) and extrinsic (e.g. pay) job characteristics (Andrisani \& Shapiro, 1978; Weaver, 1978; Witt \& Nye, 1992). Lewis (1992) obtained results, which indicated that management of problem employees does not differ significantly between the sexes, but women have more problems with their own superiors than do men. Overall, women are as satisfied as men with the fairness of their treatment, but are much more likely to say they have recently lost a job or job reward due to discrimination.

Most of the research on racial differences in job satisfaction has focused on black and white differences in America. The data have shown fairly consistently that African American workers are not as satisfied as Caucasian workers (Slocum \& Strawser, 1982; Weaver, 1977), although the differences are usually not large.

\section{Organisational Commitment}

Webster's dictionary (1992) defines commitment as "the state of intellectual and emotional adherence to some political, social or religious theory or action or practice...something which engages one to do something... a continuing obligation" and "the state to being obligated or bound" (as by intellectual or emotional ties). An alternative definition was "engagement or involvement" (Brown, 1996). Commitment means desire and acceptance. An individual wants to strive for the object, certain goals and values, or he or she wants to be a member in some system or social aspect (Jarvi, 1997). There is a psychological link between an individual and an object, an integration of goals and values (Allen \& Meyer, 1996). Organizational commitment refers to the strength of attachment of a person to his or her organization (Arnold, Cooper, \& Robertson, 1998).

Many of the previous studies on the positive consequences of organizational commitment have been based on Porter, Steers, Mowday, \& Boulian (1974), Meyer \& Allen (1991, 1997), and Randall (1990). Previous research has also stated that commitment is a multi-dimensional work attitude. Allen \& Meyer (1990) contended that the net sum of a person's commitment to the organization reflects each of the separable psychological states, which are affective attachment, perceived costs and obligation. Meyer \& Allen (1997) suggested that a "committed employee is one who will stay with the organization through thick and thin, attends work regularly, puts in a full day, protects company assets, and shares company goals." Positive outcomes or outputs at work will often cause higher commitment. Generally, outputs at work can mean fulfillment of the 
individual's needs - for example, an employee may have received things, which are important to him or her. Outputs could be, intrinsic in nature (such as doing a job which the worker finds interesting), and/or extrinsic in nature (pay, promotions, good working conditions, and having social interactions with fellow workers) (Mottaz, 1988). Thus, these outputs act as instruments in facilitating the level of commitment of an individual.

It is now generally accepted that employees' commitment to the organization can take various forms, and that the antecedents and consequences of each can be quite different (Meyer \& Allen, 1997; O'Reilly \& Chatman, 1986). If antecedents are positive, they cause commitment and an intention to stay in the organization and also involvement in the job. Research within this perspective has tended to focus on individual differences as antecedents of commitment, revealing that factors such as age and organizational tenure tend to co-vary with one's position in the organization and are known to positively correlate with commitment (Allen \& Meyer, 1990; Angle \& Perry, 1981; Lok \& Crawford, 2001; Mathieu \& Zajac, 1990; Mowday, Porter, \& Steers, 1982; Steers, 1977; Williams \& Hazer, 1986). Mathieu \& Zajac (1990) further suggested that older workers are more satisfied with their job, receiving better positions and having "cognitively justified" their remaining in the organization.

However, the relationship between age and organisational commitment is not as clear-cut as the above studies seem to suggest. The proposition that younger and older workers may view work and self in fundamentally different ways is not new. Life-career-stage models expressed by Levinson, Darrow, Klein, Levinson, \& McKee (1978) suggested that the early years are years of establishment (e.g., establishing a niche and "making it" so that progress can be monitored by self and others), the later years are associated with a stronger sense of self, work, and life. Nevertheless, Irving, Coleman \& Cooper (1997) found that age did not significantly correlate with either normative or affective facets of commitment. They concluded that age could be a significant correlate of commitment in a homogeneous sample rather than in a heterogeneous sample like theirs. In addition, findings by other scholars (Tan \&
Akhtar, 1998) also support the fact that age correlated negatively with normative and affective commitment.

In terms of gender, Aven, Parker, \& McEvoy (1993) found that gender and affective commitment were unrelated. In addition, research done in the past reports a weak relationship between gender and commitment (Mathieu $\&$ Zajac, 1990). There have also been researches indicating that gender has no direct effect on the overall organizational commitment (Ngo \& Tsang, 1998; Parasuraman \& Greenhaus, 1993).

As mentioned above, organizational commitment could be divided into 3 components, which are affective, normative, and continuance commitment. As Allen \& Meyer (1990) stated, "Employees with strong affective commitment remain because they want to, those with strong continuance commitment remain because they need to, and those with strong normative commitment remain because they feel they ought to do so". However, the current research adopts the simple approach of Hunt, Wood \& Chonko (1989) that treats organisational commitment as a single construct and does not make distinctions between the three aforesaid components of commitment.

While the above-mentioned literature explored the relationships between the variables of ethics, organisational commitment and job satisfaction on the one hand, and the demographic variables on the other, there seems to be a lack of literature on how ethics, organizational commitment and job satisfaction could be related to one another. Thus, it is the primary aim of this research to fill in that literature gap. It is reasonable to propose a theory that people who are more satisfied tend to feel more attached towards the organization and vice-versa. It is also conceivable that people who are ethical also tend to have feelings of loyalty towards the organization. Although these relationships sound logical, empirical support is needed. Thus, this leads us to the following primary research questions: Are ethical people more satisfied? Are ethical people more committed to the organisation? Are satisfied people more committed to the organisation?

In connection with the above-mentioned research questions, the following alternative hypotheses pertaining to the main research are as 
follows (null hypotheses are not listed to maintain brevity):

- H1: There is a significant positive correlation between ethics and job satisfaction.

- $\quad \mathrm{H} 2$ : There is a significant positive correlation between ethics and organisational commitment.

- H3: There is a significant positive correlation between job satisfaction and organisational commitment.

This study aims to replicate the findings of Mehta $\&$ Keng (1984) which suggested that job position, age and income were significantly correlated to perceptions of unethical situations in that the higher the position, age or income of the executives, the more unethical the situations were perceived to be. Consequently, the following hypotheses were developed as follows:

- H4: There is a significant negative correlation between ethical decision-making and age.

- H5: There is a significant negative correlation between ethical decision-making and position.

This study also aims to replicate the findings of Mathieu \& Zajac (1990) which suggested that older people are more satisfied with their jobs.

- H6: There is a significant positive correlation between job satisfaction and age.

- H7: There is a significant positive correlation between job satisfaction and position.

In order to resolve the apparent conflict between Irving, Coleman, \& Cooper (1997) and Allen \& Meyer (1990) who found an absence and a presence of a positive correlation (respectively) between organisational commitment and age, the following hypothesis was developed:

- H8: There is a significant positive correlation between organisational commitment and age.
This study aims to replicate the findings of Tan \& Akhtar (1998) who found that organizational position correlates negatively with normative and affective commitment.

- H9: There is a significant negative correlation between organisational commitment and position.

\section{RESEARCH METHODOLOGY}

The sample size for this study was 200 employees from public and private companies in various organizations in Kuala Lumpur. The data was collected from February to March 2003. The questionnaires were hand-delivered to the respondents. Although the quota (non-probability) sampling method was used, some attempts were made to ensure that the samples were heterogeneous and somewhat representative of the white-collar population. Respondents of all ages were selected somewhat equally and the respondents were employees from a variety of public and private companies in Kuala Lumpur. There were roughly the same number of male and female respondents, and most of the respondents' incomes (40\%) ranged from RM2,000 to RM4,000. Moreover, the majority of the respondents $(67 \%)$ had a bachelors' degree as their highest qualification.

In order to overcome the objection or question of validity and reliability, questionnaires that have previously been used by other researchers and published in refereed international journals, have been adopted in this study. The research instruments were:

Two ethical decision-making scenarios were utilized for measuring ethical level. Scenarios have been commonly used as part of data gathering instruments in numerous business ethics studies (i.e. Chonko \& Hunt, 1985; Singhapakdi \& Vitell, 1990; Singhapakdi, Vitell $\&$ Kraft, 1996). The utilization of scenarios helps to standardize the social stimulus across respondents and at the same time makes the decisionmaking situation more real.

Scenario 1 was as follows: "A high-ranking official in another country, where extraordinary payments to facilitate the decision-making 
process are common, asks for a $\$ 200000$ "consulting fee". In return, he/she promises special assistance in obtaining a $\$ 100$ million contract that should produce at least a $\$ 5$ - $\$ 6$ million profit for your company over the next 3 years." The respondent was to indicate on a 7-point scale ranging from strongly disagree to strongly agree as to whether he/she is likely to pay the bribe.

Scenario 2 was as follows: "The current marketing and advertising campaign for a new consumer product is offensive to some groups that have expressed their objections. However, the product has been very successful in terms of sales and profits." The respondent was to indicate on an identical 7-point scale ranging from strongly disagree to strongly agree as to whether he/she is likely to continue the advertising campaign in its current form.

Scenario 1 employed in the present study has been utilized in previous data gathering studies (i.e. Dornhoff \& Tankersley, 1975; Singhapakdi et al., 1990; Singhapakdi et al., 1996). Scenario 2 was developed by Paolillo \& Vitell (2002) and was pre-tested for face validity.

Ethical level was measured by asking the respondents to indicate whether they would act in the same manner as the individual depicted in the scenario. Specifically, the statement used in this study was, "I would act in the same manner as did the individual in the above scenario." A sevenpoint strongly agree/disagree scale measured this ethical intentions construct. Since the action depicted in the scenario was ethically questionable, agreement with the action in the scenario indicated a lower level of ethics than did disagreement.

Dubinsky \& Hartley's (1986) uni-dimensional five-item scale was used to measure job satisfaction. One of the items, for example, gives the statement, "Generally speaking, I am very satisfied with this job." Respondents indicated their response on a seven-point scale ranging from "strongly agree" to "strongly disagree". Hunt, Wood \& Chonko's (1989) four-item scale measured the respondents' organizational commitment. Examples are "I would be willing to change companies if the new job offered more creative freedom" and "I would be willing to change companies if the new job offered a 25 percent pay increase." Respondents indicated their response on a seven-point scale ranging from "strongly agree" to "strongly disagree".

\section{RESULTS}

Tests of reliability were conducted on all three scales. The Cronbach coefficient alphas are 0.5, 0.72 and 0.83 in respect of the ethics, job satisfaction, and organisational commitment scales. According to Nunnally (1978), alphas should never drop below 0.7. Certainly job satisfaction and organizational commitment have met this requirement and although the alpha for ethics is somewhat low at 0.5 , one is to bear in mind that there are only two items in this questionnaire. Thus, it can be argued that under the circumstances, such a level of reliability is fairly acceptable.

Tests of correlation were then conducted in respect of the variables of age, gender, experience, qualifications, position, ethics, job satisfaction, and organisational commitment. The results are as displayed in Table 1.

Regarding hypothesis 1 , there is no significant correlation between ethics and job satisfaction. This suggests that people who are satisfied with their jobs are not necessarily ethical, and that people who are ethical are not necessarily satisfied with their jobs. This is indeed a very important contribution to knowledge in that a high level of ethics can either improve job satisfaction or have a detrimental effect on it. Support for hypothesis 2 was obtained in that there is positive correlation between ethics and organisational commitment $(r=.195, \mathrm{p}<0.01)$. This suggests that ethical people are more committed towards the organisation, or that committed people are more ethical. Support for hypothesis 3 was obtained in that there is a significant positive correlation between job satisfaction and organisational commitment $(r=.239, p<0.01)$. This suggests that satisfied people are committed, or that committed people are satisfied with their jobs.

No supports were found for hypotheses 4 and 5 in that there were no significant correlations between ethics and age and between ethics and position. Thus results in this study did not 
Table 1

Correlations

\begin{tabular}{|l|l|l|l|l|l|}
\hline & Ethics & Org Comm & Job sat & Position & Age \\
\hline Ethics & 1 & & & & \\
\hline Org comm & $.195^{* *}$ & 1 & & & \\
\hline Job sat & -.098 & $.239^{* *}$ & 1 & & \\
\hline Position & -.076 & $-.288^{* *}$ & $-.217^{* *}$ & 1 & \\
\hline Age & .108 & .134 & $.204^{* *}$ & $.389^{* *}$ & 1 \\
\hline Experience & .053 & .134 & $.245^{* *}$ & $.330^{* *}$ & $.838^{* *}$ \\
\hline
\end{tabular}

$* *=$ Correlations, $\mathrm{p}<0.01$

Table 2

Gender t-tests

Independent Samples Test

\begin{tabular}{|c|c|c|c|c|c|c|c|c|c|c|}
\hline & \multicolumn{2}{|c|}{$\begin{array}{l}\text { Levene's } \\
\text { Test for } \\
\text { quality of } \\
\text { Variance }\end{array}$} & \multicolumn{7}{|c|}{ t-test for Equality of Means } \\
\hline & & \multirow{2}{*}{$\mathrm{F}$} & \multirow{2}{*}{ Sig. } & \multirow{2}{*}{$\mathrm{t}$} & \multirow{2}{*}{ df } & \multirow{2}{*}{$\begin{array}{c}\text { sig. } \\
(2- \\
\text { tailed })\end{array}$} & \multirow{2}{*}{$\begin{array}{c}\text { Mean } \\
\text { Difference }\end{array}$} & \multirow{2}{*}{$\begin{array}{l}\text { Std. Error } \\
\text { Difference }\end{array}$} & \multicolumn{2}{|c|}{$\begin{array}{l}95 \% \text { Confidence } \\
\text { Interval of the } \\
\text { Difference }\end{array}$} \\
\hline & & & & & & & & & Lower & Upper \\
\hline Job Sat & $\begin{array}{l}\text { Equal variance } \\
\text { assumed } \\
\text { Equal variance } \\
\text { not assumed }\end{array}$ & .125 & .724 & $\begin{array}{l}-2.369 \\
-2.362\end{array}$ & $\begin{array}{r}198 \\
192.747\end{array}$ & $\begin{array}{l}.019 \\
.019\end{array}$ & $\begin{array}{l}-1.6351 \\
-1.6351\end{array}$ & $\begin{array}{l}.69013 \\
.69238\end{array}$ & $\begin{array}{l}2.99604 \\
3.00071\end{array}$ & $\begin{array}{l}-.27413 \\
-.26947\end{array}$ \\
\hline Ethics & $\begin{array}{l}\text { Equal variance } \\
\text { assumed } \\
\text { Equal variance } \\
\text { not assumed }\end{array}$ & .091 & .763 & $\begin{array}{l}.408 \\
.407\end{array}$ & $\begin{array}{r}198 \\
195.116\end{array}$ & $\begin{array}{l}.684 \\
.684\end{array}$ & $\begin{array}{l}.0855 \\
.0855\end{array}$ & $\begin{array}{l}.20956 \\
.20978\end{array}$ & $\begin{array}{l}-.32780 \\
-.32827\end{array}$ & $\begin{array}{l}.49872 \\
.49920\end{array}$ \\
\hline $\begin{array}{l}\text { Org } \\
\text { Commit }\end{array}$ & $\begin{array}{l}\text { Equal variance } \\
\text { assumed } \\
\text { Equal variance } \\
\text { not assumed }\end{array}$ & .091 & .340 & .283 & $\begin{array}{r}198 \\
196.990\end{array}$ & $\begin{array}{l}.779 \\
.777\end{array}$ & $\begin{array}{l}.2015 \\
.2015\end{array}$ & $\begin{array}{l}.71742 \\
.71129\end{array}$ & $\begin{array}{l}1.21327 \\
1.20121\end{array}$ & $\begin{array}{l}1.61628 \\
1.60422\end{array}$ \\
\hline
\end{tabular}


conform to those in Mehta \& Keng (1984) that found a negative correlation between ethics on the one part and age and position on the other. Support for hypothesis 6 was found in that there is a significant positive correlation between job satisfaction and age $(r=.204, p<0.01)$. This is consistent with Mathieu \& Zajac (1990), who found that job satisfaction increases with age. Support for hypothesis 7 was found in that there is a significant positive correlation between job satisfaction and position $(\mathrm{r}=-.288, \mathrm{p}<0.01)$ which suggests that job satisfaction also increases with position.

Regarding hypothesis 8, consistent with the findings of Irving, Coleman \& Cooper (1997), there was no significant correlation between organisational commitment and age. Consistent with the findings of Tan \& Akhtar (1998), support was obtained for hypothesis 9 in that organisational commitment had a negative correlation with position $(\mathrm{r}=-0.288, \mathrm{p}<0.01)$. This suggests that people higher up in the hierarchy are less committed towards the organisation and perhaps frequently think of leaving the organisation in search of better jobs.

T-tests revealed that males are more satisfied at work than females. t-tests also suggest that neither sex group is more ethical nor more committed than the other. Results of the t-tests are displayed in Table 2.

\section{DISCUSSION}

The results of this study contributed to knowledge in that it has revealed a relationship that has not been found in previous reported studies: a significant positive correlation between ethics and organisational commitment. This suggests that ethical people are more committed to the organisation, or that committed people are more ethical. Also interesting is that contrary to previous studies, no significant relationship was found between ethics and job satisfaction. However, consistent with previous studies, the current research found a positive relationship between job satisfaction and organisational commitment.
The absence of any significant correlation between ethics and age, and between ethics and position is contrary to previous studies conducted in the West. Perhaps, this is a uniquely Malaysian phenomenon in that ethics remains somewhat stable during adult-hood. However, in connection with the relationship between job satisfaction and age, and experience, the findings in this study are consistent with those of previous studies. Consistent with a previous study, higher-level employees are less committed to the organisation and less satisfied than lower-level employees. This may be because higher-level employees receive greater job prospects outside the organisation compared to the lower-level employees. Organisations should therefore ensure that they have an attractive career path and opportunities for further growth, even for their higher-level staff.

\section{Suggestions for Future Research}

There are many interesting findings of this study. The absence of a significant correlation between ethics and satisfaction, either positive or negative, suggests that in some circumstances a high level of ethics can enhance job satisfaction whereas in other circumstances a high level of ethics can actually result in lower job satisfaction. It is also possible that the relationship between ethical decision-making and satisfaction at work could be moderated by some other variable. Although it is purely conjectural at this stage, one such variable could be the level of autonomy in decision-making. One could theorise that where an individual is given a high level of autonomy, that individual is able to make decisions consistent with his/her high ethical principles - hence a high level of satisfaction would result. However, if an individual is not given sufficient autonomy in decision-making, the individual can be forced to make decisions contrary to his/her high ethical principles hence lower satisfaction. Although the current data have not identified autonomy as such a variable, the results seem to suggest that there is no clearcut relationship between ethics and satisfaction, thus hinting that there is a possibility of the existence of moderator(s). Perhaps future research should investigate such issues. 


\section{REFERENCES}

Allen, N. J. \& Meyer, J. P. (1990). The measurement and antecedents of affective, continuance and normative commitment to the organization. Journal of Occupational Psychology, 63, 1-18.

(1996). Affective, continuance, and normative commitment to the organization: An examination of construct validity. Journal of Vocational Behavior, 49, 252-276.

Andrisani, P. J. \& Shapiro, M. B. (1978). Women's attitudes toward their jobs: some longitudinal data on a national sample. Personnel Psychology, 31, 15-34.

Angle, H. L. \& Perry, J. L. (1981). An empirical assessment of organizational commitment and organizational effectiveness. Administrative Science Quarterly, 21, 1-14.

Arnold, J., Cooper, C. L., \& Robertson, I. T. (1998). Work psychology: understanding human behavior in the workplace ( $3^{\text {rd }}$ ed.). London : U.K Financial Times.

Aven, F. F., Parker, B., \& McEvoy, G. M. (1993). Gender and attitudinal commitment to organizations: a meta-analysis. Journal of Business Research, 26, 63-73.

Becker, L. B., Sobowale, I. A. \& Cobbey, R. E. (1979). Reporters and their professional and organizational commitment. Journalism Quarterly, 56, 753-763, 770.

Bourne, B. (1982). Effects of aging on work satisfaction, performance and motivation. Aging and Work, 5, 37-47.

Brown, R. B. (1996). Organizational commitment: clarifying the concept and simplifying existing construct typology. Journal of Vocational Behavior, 49, 230-251.
Brush, D. H., Moch, M. K. \& Pooyan, A. (1987). Individual demographic differences and job satisfaction. Journal of Occupational Behaviour, 8, 139-156.

Chonko, L. B. \& Hunt S. D. (1985). Ethics and marketing management: an empirical examination. Journal of Business Research, 13, 339-359.

DeCotiis, T. A. \& Summers, T. P. (1987). A path analysis of a model of the antecedents and consequences of organizational commitment. Human Relations, 40, 445-470.

Dipboye, R. L., Smith, C. S. \& Howell, W. C. (1994). Understanding iIndustrial and organizational psychology. Orlando, Florida: Harcourt Brace and Company.

Dornhoff, R. J. \& Tankersley, C. B. (1975). Perceptual differences in market transactions: a source of consumer frustration. Journal of Consumer Affairs, 9, 97-103.

Dubinsky, A. J. \& Hartley, S. (1986). A path analytic study of a model of salesperson performance. Journal of the Academy of Marketing Science, 14, 36-46.

Ferrel, O. C. \& Gresham, L. G. (1985). A contingency framework of understanding ethical decision-making in marketing. Journal of Marketing 49, 87-96.

Herzberg, F., Mausner, B. \& Snyderman, B. (1959). The motivation to work. New York: John Wiley and Sons.

Hulin, C. L. \& Smith, P. C. (1964). Sex differences in job satisfaction. Journal of Applied Psychology, 48, 88-92.

Hunt, S. D., Wood, J. \& Chonko, L. B. (1989). Corporate ethical values and organizational commitment in marketing. Journal of Marketing, 53, 70-90. 
Hunt, J. W. \& Saul, P. N. (1975). The relationship of age, tenure, and job satisfaction in males and females. Academy of Management Journal, 18, 690-702.

Hunt, S. D. \& Vitell, S. J, (1986). A general theory of marketing ethics. Journal of Macromarketing, 8, 5-16.

Irving, P. G., Coleman, D. F., \& Cooper, C. L. (1997). Futher assessment of a three-component model of occupational commitment: Generalizability and Differences Across Occupations. Journal of Applied Psychology, 82, 444-452.

Jarvi, P. (1997). Commitment and occupational image. The occupational image as a part of the vocational oriented process. series A-10. The Turku School of Economics and Business Administration: Turku.

Levinson, D. J., Darrow, C. N., Klein, E. B., Levinson, M. H., \& McKee, B. (1978). The seasons of a man's life. New York: Ballantine Books.

Lewis, G. B. (1992). Men and women toward the top - backgrounds, careers and potential of federal middle managers. Public Personnel Management, 21,(4), 473-491.

Lok, P. \& Crawford, J. (2001). Antecedents of organizational commitment and the mediating role of job satisfaction. Journal of Managerial Psychology, 16, (8), 594-613.

Mathieu, J. E. \& Zajac, D. M. (1990). A review and meta-analysis of the antecedents, correlates, and consequences of organizational commitment. Psychological Bulletin, 108, 171-194.

Mehta, S. C. \& Keng, K. A. (1984). Marketing executives, Perceptions of unethical practices: An empirical investigation of Singapore managers. Singapore Management Review, 6 (2) 25-35.
Meyer, J. P. \& Allen, N. J. (1991). A three-component conceptualisation of organizational commitment. Human Resource Management Review, 1,(1), 61-89.

(1997). Commitment in the workplace: theory, research, and application. Thousand Oaks, CA : Sage.

Mottaz, C. J. (1988). Determinants of organizational commitment. Human Relations, 6, 467-482.

Mowday, R. T., Porter, L. W., \& Steers, R. M. (1982). Employee-organizational linkages: The psychology of commitment, absenteeism, and turnover. New York: Academic Press.

Ngo, H. Y. \& Tsang W. N. (1998). Employment practices and organizational commitment: differential effects for men and women? International Journal of Organizational Analysis, 6,(3), 251-266.

Nunnally, J. O. (1978). Psychometric Theory. New York: McGraw-Hill.

O'Reilly, C. A., \& Chatman, J. (1986). Organizational commitment and psychological attachment: the effects of compliance, identification, and internalization on Pro-social behavior. Journal of Applied Psychology, 71, 492-499.

Ostroff, C. \& Rothausen, T. J. (1997). The moderating effect of tenure in person-environment fit: A field study in educational organizations. Journal of Occupational and Organizational Psychology, 70, (2), 173188.

Paolillo, J. G. P. \& Vitell, S. J. (2002). An empirical investigation of the influence of selected personal organizational and moral intensity factors on ethical decision-making. Journal of Business Ethics 35, 65-74. 
Parasuraman, S., \& Greenhaus, J. H. (1993). Personal portrait: The life-style of the woman manager. In E.A. Fagenson (Ed.). Women in Management: Trends, Issues, and Challenges in Managerial Diversity, 186-211.

Pond, S. B. III, \& Geyer, P. D. (1987). Employee age as a moderator of the relation between perceived work alternatives and job satisfaction. Journal of Applied Psychology, 72, 552-557.

Porter, L. W., Steers, R. M., Mowday, R. T., \& Boulian, P. V. (1974). Organizational commitment, job satisfaction, and turnover among psychiatric Technicians. Journal of Applied Psychology, 59, 603-609.

Randall, D. M. (1990). The consequences of organizational commitment: methodological investigation. Journal of Organizational Behavior, 11, 361-378.

Rhodes, S. R. (1983). Age-related differences in work attitudes and behavior: A review and conceptual analysis. Psychological Bulletin, 93, 328-367.

Singhapakdi, A. \& Vitell S. J. (1990). Marketing ethics: factors influencing perceptions of ethical problems and alternatives. Journal of Macro-marketing 12, 4-18.

Singhapakdi, A., Vitell S. J. \& Kraft, K. L. (1996). The perceived role of ethics and social responsibility. Journal of Business Ethics 15, 1131-1140.

Slocum, J. W. \& Strawser, R. H. (1982). Racial differences in job attitudes. Journal of Applied Psychology, 62, 16-19.

Smith, C. S., Olsen, H. \& Falgout, K. (1991). A career path investigation of job-related attitudes and behaviors. Poster presented at the Sixth Annual Conference of the Society for Industrial and Organizational Psychology, St. Louis.

Steers, R. M. (1977). Antecedents and outcomes of organizational commitment. Administrative Science Quarterly, 22, 46-56.

Tan, S. K. \& Akhtar, S. (1998). Organizational commitment and experienced burnout: an exploratory study from a Chinese cultural perspective. International Journal of Organizational Analysis, 6, (4), 310-333.

Weaver, C. N. (1977). Relationship among pay, race, sex occupational prestige, supervision, work autonomy and job satisfaction in a national sample. Personnel Psychology, 30, 437-445.

(1978). Black-white correlates of job satisfaction. Journal of Applied Psychology, 63, 255-258.

Webster (1992). New Webster's Dictionary and Thesaurus of the English Language. Danbury: Lexicon Publication's, Inc.

Wilk, S. L., Desmarais, L. B. \& Sackett, P. R. (1995). Gravitation to jobs commensurate with ability: longitudinal and cross-sectional tests. Journal of Applied Psychology, 80, (1), 79-85.

Williams, L. J. \& Hazer, J. T. (1986). Antecedents and consequences of satisfaction and commitment in turnover models. A Reanalysis using Latent Variable Structural Equation Methods. Journal of Applied Psychology, 71, 219-231.

Witt, L. A. \& Nye, L. G. (1992). Gender and the relationship between perceived fairness of pay or promotion and job satisfaction. Journal of Applied Psychology, 77, (6), 910917. 